\title{
PEMODELAN PENGENALAN CITRA WAJAH MENGGUNAKAN TRANSFORMASI WAVELET DAUBECHIES 1 DAN JARINGAN SARAF TIRUAN (JST) BACKPROPAGATION
}

\author{
Rangga Farras Alsajid ${ }^{1}$, \\ Program Studi Teknik Elektro Universitas Trisakti \\ Email: rangga062001600007@std.trisakti.ac.id \\ Suhartati Agoes, ${ }^{1}$ \\ Program Studi Teknik Elektro Universitas Trisakti \\ Email: sagoes@trisakti.ac.id \\ Henry Candra ${ }^{1}$ \\ Program Studi Teknik Elektro Universitas Trisakti \\ Email: henrycandra@trisakti.ac.id
}

\begin{abstract}
S : The current use of traditional house keys is still considered very less secure so that other methods are needed to improve the level of security. Humans have their own unique characteristics to distinguish one human from another. One of them is the face. This study aims to create an automatic modelling system that can detect a person's face. This modelling system is expected to be able to make a decision whether the person who will enter the house is a occupants of the house or someone else. This automated modelling system uses digital image processing. Feature extraction in this modelling system uses the Wavelet Dauechies 1 Transformation and for its classification uses the Backpropagation Neural Network method. This modelling system experimented 30 times for occupants with 28 successes and 2 failures. Meanwhile, for non-occupants, 30 trials were carried out with a result that 30 times successfully refused entry. This modelling system has an accuracy of 97.33\% with an error of 0.38, the Mean Absolute Percentage of $26.23 \%$ and the Mean Square Error of 0.38 .
\end{abstract}

Keyword: Image Processing, Face Recognition, Wavelet Transformation, Artificial Neural Network Backpropagation

\begin{abstract}
ABSTRAK: Penggunaan kunci rumah saat ini yang masih tradisional dirasa masih sangat kurang keamanannya sehingga dibutuhkan metode lain untuk memperbaiki tingkat keamanannya. Manusia memiliki ciri khas masing masing untuk membedakan manusia yang satu dengan yang lainnya. Salah satu ciri khas pada manusia adalah wajah. Penelitian ini mempunyai tujuan untuk membuat sistem pemodelan otomatis yang bisa mendeteksi wajah seseorang. Sistem pemodelan ini diharapkan bisa mengambil sebuah keputusan apakah orang yang akan masuk ke dalam rumah merupakan penghuni rumah atau orang lain. Sistem pemodelan otomatis ini menggunakan pengolahan citra digital. Ekstraksi ciri pada sistem pemodelan ini menggunakan Transformasi Wavelet Dauechies 1 dan untuk klasifikasinya menggunakan metode Jaringan Saraf Tiruan Backpropagation. Sistem pemodelan ini melakukan percobaan sebanyak 30 kali untuk penghuni dengan hasil 28 kali berhasil dan 2 kali gagal. Sedangkan untuk yang bukan penghuni dilakukan percobaan sebanyak 30 kali percobaan dengan hasil 30 kali berhasil ditolak masuk. Sistem pemodelan ini mempunyai akurasi 97,33\% dengan Error sebesar 0,38, Mean Absolute Percentage nya sebesar 26,23\% dan Mean Square Error nya sebesar 0,38.
\end{abstract}

Kata Kunci: Pengolahan Citra,Pengenalan wajah, Transformasi Wavelet, Jaringan Saraf Tiruan Backpropagation.

\section{PENDAHULUAN}

Tentifikasi wajah adalah suatu kegiatan penetapan identitas seseorang dan hewan. Banyak cara yang bisa dilakukan untuk mengidentifikasi wajah suatu objek, salah satunya dengan mengambil sesuatu yang khas dari objek tersebut. Pada dasarnya manusia memiliki ciri khas yang bisa digunakan untuk membedakan dirinya dengan manusia yang lain. Beberapa ciri khas yang dapat membedakan manusia dengan yang lainnya adalah sidik jari, iris mata, Deoxyribonucleic acid(DNA) dan wajah. Berangkat dari hal ini, berkembanglah suatu inovasi teknologi yang memanfaatkan ciri khas pada setiap orang untuk meningkatkan keamanan menggunakan proses pengolahan citra digital [1].

Transformasi Wavelet merupakan salah satu pendekatan kuat terhadap pemrosesan dan analisis sebuah sinyal. Transformasi ini berbasis pada gelombang kecil yang disebut Wavelet. Metode ini mempunyai kemudahan dalam kompresi,transmisi dan analisis citra. Transformasi ini ada 2 jenis yaitu Transformasi Wavelet Kontinu (TWK) dan Transformasi Wavelet Diskrit (TWD) yang membedakannya adalah sampling dari masing masing jenis wavelet ini. Untuk pengklasifikasian dari citra, Wavelet jenis Daubechies menjadi jenis yang paling baik dibandingkan dengan Wavelet Haar [2].

Jaringan Saraf Tiruan (JST) merupakan suatu cara untuk pengambilan keputusan dan pengenalan dari hasil suatu proses pencirian citra digital. Metode ini mempunyai kelebihan yaitu mampu mengakuisisi pengetahuan pembelajaran dan juga memiliki tingkat kesalahan yang sangat kecil [3]. Algoritma ini

\footnotetext{
1 Program Studi Teknik Elektro Universitas Trisakt
} 
dikembangkan melalui pembelajaran otak manusia. Algoritma ini bisa diaplikasikan ke dalam program komputer yang nantinya bisa menyelesaikan beberapa masalah perhitungan dalam pembelajaran [4].

\section{Pengolahan Citra Digital}

\section{LANDASAN TEORI}

Pengolahan citra digital merupakan suatu ilmu mengenai pengolahan citra diam maupun bergerak secara digitalisasi. Citra bisa diolah secara digital apabila direpresentasikan dalam numerik dengan nilai yang diskrit . Citra digital dapat dipresentasikan dalam matriks $\mathrm{M}$ x N dimana $\mathrm{M}$ merupakan baris dan $\mathrm{N}$ adalah kolom dari matriks MN. Diantara baris M dan kolom N mempunyai perpotongan yang biasa disebut piksel [5]. Beberapa jenis citra digital yaitu :

1. Citra Berwarna (Red, Green, Blue)

Citra berwarna ialah citra yang setiap komposisi warnanya merupakan bagian dari 3 komponen warna utama (Red, Green, Blue). Setiap warna masing masing memiliki nilai 8 bit, yang berarti citra berwarna memiliki 16 juta warna yang dihasilkan dari kombinasi 3 warna utama. Setiap warna juga mempunyai rentang dari 0 hingga 255 [5].

2. Citra Grayscale

Citra Grayscale ini adalah citra yang mempunyai nilai intesitas pikselnya berdasarkan dari derajat keabuan. Pada grayscale 8-bit nilai derajat warna hitam sampai putih dibagi dalam 256 derajat keabuan. Pada warna putih sempurna derajat keabuannya bernilai sebesar 255 sedangkan warna hitam sempurna bernilai 0 [5].

\section{Pendeteksian Wajah}

Metode yang banyak digunakan pada pendeteksian wajah saat ini adalah Viola Jones banyak digunakan dalam dikarenakan metode ini mempunyai algoritma yang ringan untuk mendeteksi wajah dan berbagai landmark wajah termasuk mata dan mulut. Algoritma ini mempunyai kompleksitas yang rendah sehingga cocok untuk pengaplikasian pada waktu yang sedikit [6].

Tahap dalam pendeteksian wajah menggunakan metode Viola Jones dimulai dengan memberikan citra masukan, melokalisasi entitas wajah dengan ukuran sembarang $\mathrm{F}_{-}(\mathrm{m} \times \mathrm{n})$ dilanjutkan dengan menstandarisasikan ukuran citra dan citra yang sudah sesuai ukuran akan terbagi menjadi 2 bagian. Bagian atas dimana terdeteksi bagian mata dan bagian bawah yang terdeteksi bagian mulut [6].

Metode Viola Jones mempunyai Fitur Haar yang merupakan fitur untuk dua dimensi yang disebut sebagai satu terang dan satu gelap. Fitur Haar ditentukan dengan cara mengurangi rata-rata piksel pada daerah gelap dari rata-rata piksel pada daerah terang. Selanjutnya untuk menentukan ada atau tidaknya dari ratusan fitur Haar pada sebuah gambar dan pada skala yang berbeda secara efisien digunakan Integral Image.

\section{Integral Image}

Integral image adalah sebuah citra yang nilai tiap pikselnya merupakan penjumlahan dari nilai piksel kiri atas hingga kanan bawah.
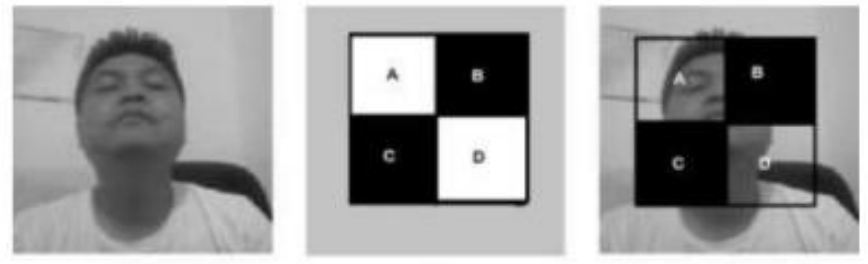

Gambar 1. integral image

Untuk mengetahui nilai piksel nya dapat menggunakan integral image untuk beberapa segiempat yang lain misalkan, contoh pada segiempat D di Gambar 2.2 integral image bisa kita lakukan dengan cara menggabungkan jumlah piksel pada area segiempat $\mathrm{A}+\mathrm{B}+\mathrm{C}+\mathrm{D}$, lalu dikurangi jumlah segiempat dalam yaitu segiempat $\mathrm{A}+\mathrm{B}$ dan $\mathrm{A}+\mathrm{C}$, ditambah jumlah piksel di dalam $\mathrm{A}$. 
Dengan $\mathrm{A}+\mathrm{B}+\mathrm{C}+\mathrm{D}$ adalah nilai dari integral image pada lokasi $4, \mathrm{~A}+\mathrm{B}$ adalah nilai pada lokasi 2, $\mathrm{A}+\mathrm{C}$ adalah nilai pada lokasi 3, dan A pada lokasi 1. Sehingga hasil dari $\mathrm{D}$ dapat dikomputasikan

$$
D=(A+B+C+D)-(A+B)-(A+C)+A \text {.. }
$$

\section{Adaboost}

Metode AdaBoost mengoptimalkan model klasifikasi dari training set yang diberikan. Viola and Jones mengusulkan beberapa classifier lemah yang dilatih menggunakan AdaBoost sehingga menghasilkan classifier yang kuat untuk mendeteksi wajah.

\section{Transformasi Wavelet}

Transformasi wavelet adalah sebuah fungsi yang mampu melakukan dekomposisi suatu fungsi. Transformasi wavelet juga merupakan sebuah metode aproksimasi dari suatu fungsi basis wavelet $\psi(\mathrm{t})$ dengan bantuan lokalisasi waktu dan frekuensi. Untuk melakukan aproksimasi dibutuhkan fungsi lain yang didefinisikan sebagai fungsi $\psi$ dengan pembatasan [7].

$$
\int_{-\infty}^{\infty} \psi(t) d t=0 .
$$

Untuk Wavelet hampir mendekati dengan transformasi fourier, jika Fourier hanya membolehkan penempatan dalam fungsi waktu, Wavelet membolehkan penempatan waktu dalam komponen frekuensi yang berbeda-beda.

Transformasi Wavelet sendiri, dibagi menjadi dua yaitu kontinu dan diskrit yang diturunkan dari mother wavelet melalui pergeseran dan penskalaan dekomposisi. Oleh sebab itu, karakteristik transformasi yang dihasilkan bergantung pada mother wavelet itu sendiri [8].

\section{Transformasi Wavelet Kontinu (TWK)}

Cara kerja dari transformasi ini yaitu dengan menghitung konvolusi sebuah sinyal pada sebuah windowing, dimana windowing mempunyai tingkat fleksibilitas yang tinggi yang biasa disebut mother wavelet [9].

\section{Transformasi Wavelet Diskrit (TWD)}

Prinsip dasar TWD adalah bagaimana mendapatkan representasi waktu dan skala dari sebuah sinyal menggunakan teknik pemfilteran digital. Transformasi Wavelet Diskrit (TWD) adalah salah satu metode yang dipakai untuk representasi dan analisis sinyal diskrit. Kelebihan dari TWD adalah pada saat yang bersamaan dapat memberikan informasi frekuensi dan informasi temporal, berbeda dengan Discrete Fourier Transform (DFT) dan Discrete Cosine Transform (DCT) yang hanya dapat menghasilkan informasi frekuensi. Maka dari itu, TWD banyak digunakan untuk menganalisis timefrequency sebuah sinyal masukan [9].

\section{Dekomposisi Wavelet Diskrit}

Pada proses ini, merupakan tahap pengambilan ciri dari citra masukan dengan menggunakan metode Transformasi Wavelet diskrit. Proses utama Transformasi Wavelet diskrit adalah dekomposisi dimana dimulai dengan dekomposisi baris yang diikuti dengan dekomposisi kolom. Citra difilter menggunakan High Pass Filter (HPF) dan Low Pass Filter (LPF) yang kemudian akan dilakukan konvolusi terhadap baris-baris pada citra yang diikuti dengan melakukan konvolusi terhadap kolomkolom pada citra untuk selanjutnya dilakukan proses downsampling [10].

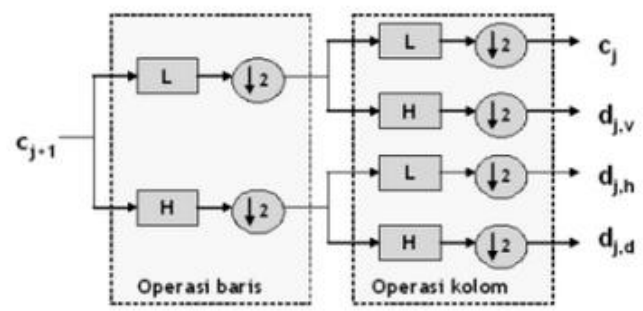

Gambar 2. Dekomposisi Wavelet Level 1[10]

Berdasarkan Gambar 2.1 dekomposisi level 1 menghasilkan sub band-sub band detail yang terdiri dari 
1. Approximation $\mathrm{c}_{\mathrm{j}}$

2. Vertikal $\mathrm{d}_{\mathrm{j}, \mathrm{v}}$

3. Horisontal $\mathrm{d}_{\mathrm{j}, \mathrm{h}}$

4. Diagonal $\mathrm{d}_{\mathrm{j}, \mathrm{d}}$

\section{Inverse Wavelet Diskrit}

Untuk mendapatkan kembali sinyal masukan yang asli diperlukan transformasi balik dengan proses yang berlawanan arah dengan proses dekomposisi dan penfilteran dengan koefisien-koefisien filter balik atau invers. Pada proses invers Transformasi Wavelet ini menggunakan fungsi dasar Wavelet serta harus menggunakan tingkat yang sama pada proses dekomposisi. Citra inilah yang akan disimpan di database untuk pembanding citra uji [11].

\section{Ekstraksi Fitur}

Sebuah citra mempunyai beberapa ciri yang berbeda. Ciri atau informasi itu yang menggambarkan citra tersebut. Pada penelitian ini beberapa parameter yang akan dipakai antara lain

\section{- Entropi}

Entropi adalah suatu nilai yang menunjukkan suatu keteracakan distribusi keabuan pada sebuah citra. Semakin acak distribusi keabuan dari suatu citra maka akan semakin besar nilai entropi citra tersebut. Menghitung nilai shannon entrophy dengan persamaan di bawah ini [12]

- Energi

$$
E_{(s)}=-\sum s_{i}^{2} \log \left(s_{i}^{2}\right)
$$

Energi merupakan kebalikan dari entropi. Nilai energi menunjukkan keterarahan dari distribusi keabuan suatu citra. Semakin besar nilai entropi maka semakin kecil nilai energi suatu citra.Energi dapat dihitung menggunakan persamaan berikut ini [12 ].

$$
E_{(s i)}=\sum_{i} \log \left(s_{i}^{2}\right)
$$

\section{Jaringan Saraf Tiruan (JST)}

Pemodelan Jaringan Saraf Tiruan didasari oleh struktur jaringan dari otak manusia. Suatu struktur Jaringan Saraf Tiruan bisa dijadikan untuk alat penghitung. Neuron atau yang biasa disebut sebagai sel saraf merupakan suatu bagian terkecil dan juga yang paling utama pada otak manusia [13].

\section{Arsitektur Jaringan Saraf Tiruan}

Beberapa fungsi yang paling utama dalam menentukan suatu Neuron adalah fungsi aktivasi dan juga pola bobotnya. Beberapa contoh arsitektur Jaringan Saraf Buatan antara lain:

1. Single Layer Net

Jaringan ini hanya memiliki satu lapisan saja dengan bobot-bobot yang terhubung. Jaringan dengan lapisan tunggal, hanya menerima input dan langsung mengolah tanpa melalui jaringan tersembunyi (hidden layer) untuk menghasilkan suatu output.

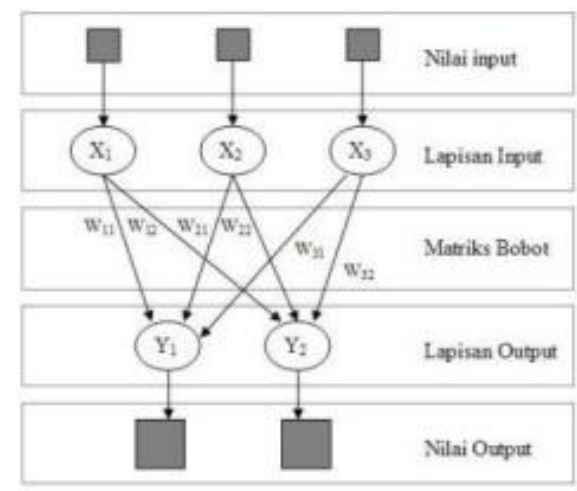

Gambar 3. Jaringan Single Layer Net [13]

2. Multi Layer Net

Jaringan ini memiliki 1 atau lebih lapisan yang berada antara lapisan input dengan lapisan output. 
Lapisan ini disebut dengan lapisan tersembunyi atau hidden layer.

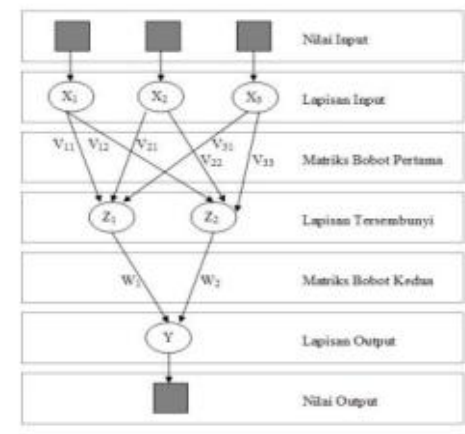

Gambar 4. Jaringan Multi Layer Net [13]

\section{Proses Pembelajaran}

Proses pembelajaran pada Jaringan Saraf Tiruan ada 2 yaitu proses pembelajaran terawasi dan proses pembelajaran tidak terawasi. Perbedaan antara 2 proses tersebut adalah output-nya. Jika proses pembelajaran terawasi, harus mengetahui output yang diharapkan diketahui terlebih dahulu. Sedangkan untuk proses pembelajaran tidak terawasi, tidak memerlukan target output [13].

Proses pembelajaran terawasi (supervised learning) sendiri ada beberapa macam yaitu

1. Perception

Biasanya digunakan untuk mengklasifikasikan pola tertentu yang biasa dikenal dengan pemisahan secara linear.

2. Delta Rule

Biasanya digunakan untuk mengubah nilai bobot pada jaringan yang menghubungkan antara input dengan output.

3. Backpropagation

Merupakan sebuah algoritma pembelajaran yang terawasi. Biasanya digunakan untuk mengklasifikasikan pola dengan banyak lapisan untuk mengubah bobot - bobot yang terhubung pada neuron di hidden layer.

\section{Algoritma Jaringan Saraf Tiruan}

Pada Jaringan Saraf Tiruan terdapat 2 tahap penting yaitu forward propagation dan Back Propagation. Perbedaan antara keduanya adalah forward propagation akan menghasilkan nilai (y) atau biasa disebut dengan output. Sedangkan Backpropagation akan selalu mencoba memperbaiki bobot dirinya sehingga output bisa menghasilkan nilai yang mendekati label yang asli.

1. Forward Propagation

Forward propagation merupakan proses perhitungan dari input hingga output. Perhitungan ini juga disebut sebagai perhitungan maju. Setiap hidden layer menerima data input lalu diproses dengan fungsi aktivasi dan berpindah ke lapisan berikutnya.

2. Backpropagation

Back ropagation merupakan proses perhitungan dari ouput ke belakang. Perhitungan ini juga disebut sebagai perhitungan mundur. Ketika sudah mendapatkan nilai error dari perhitungan forward propagation, maka akan mulai perhitungan untuk memperbaiki nilai bobot dan nilai bias (b) menggunakan Back Propagation.

\section{Parameter Kerja Sistem}

1. Mean Square Error (MSE)

Merupakan ukuran yang digunakan untuk menilai seberapa baik sebuah metode dalam melakukan pengolahan sebuah citra dalam melakukan peramalan dalam suatu periode tertentu. Mean square error dapat dihitung dengan cara menjumlahkan kuadrat semua kesalahan peramalan pada suatu periode dan membaginya dengan jumlah periode tersebut.[14].

$$
M S E=\sum \frac{\left(X_{t}-S_{t}\right)^{2}}{n}
$$




$$
\begin{aligned}
& E=\text { kesalahan } \\
& X_{t}=\text { data aktual } \\
& S_{t}=\text { data hasil peramalan } \\
& n=\text { jumlah periode peramalan }
\end{aligned}
$$

\section{Mean Absolute Percentage Error (MAPE)}

$M A P E$ merupakan pengukuran kesalahan yang menghitung ukuran presentase penyimpangan antara data aktual dengan data peramalan mean absolute percentage error (MAPE) dihitung dengan menggunakan kesalahan absolut pada tiap periode dibagi dengan nilai observasi yang nyata untuk periode itu.

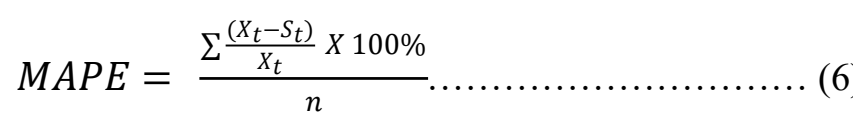

\section{METODELOGI PENELITIAN}

Pada penelitian ini pemodelan yang akan dibuat merupakan alat yang dapat mendeteksi masukan yang berupa citra digital. Citra digital kemudian akan diproses untuk dapat mendapatkan ciri dari citra dan diklasifikasi menggunakan Jaringan Saraf Tiruan yang nantinya bisa membedakan wajah penghuni rumah dengan wajah yang bukan penghuni rumah. Penelitian ini mengharapkan akurasi yang baik dimana akurasi merupakan jumlah keberhasilan dibandingkan dengan jumlah percobaan. Parameter yang akan diuji adalah ekstraksi fitur shannon entropy, log energy untuk mengeahui nilai ciri pada suatu citra. Parameter lain yang akan diuji adalah error, mean square error, dan mean absolute percentage error yang mana parameter tersebut penting untuk diketahui untuk melihat seberapa baik metode Jaringan Saraf Tiruan dalam melakukan suatu peramalan. Selain itu, penelitian ini juga akan menghitung delay yang mana merupakan waktu yang dibutuhkan dalam 1 kali pengenalan.

Arsitektur Jaringan Saraf Tiruan pada penelitian ini menggunakan Multi Layer Net dengan struktur jaringan 2-40-5-1 dimana angka 2 merupakan input dari Jaringan Saraf Tiruan yaitu hasil dari ekstraksi fitur dan angka 1 merupakan output dari Jaringan Saraf Tiruan. Sedangkan angka 40 dan angka 5 merupakan hidden layer 1 dan hidden layer 2. Jumlah hidden layer ini ditentukan pada saat proses training dengan melihat mana hasil Error yang paling kecil.

Pada tahap training citra yang akan dilatih merupakan citra dari 2 orang yang berbeda dengan 30 citra untuk masing masing orang dan posisi yang sama pada waktu yang sama untuk ke 30 citranya. Pada penelitian ini orang pertama merupakan penghuni rumah yang memiliki nilai target 1 dan orang kedua merupakan bukan penghuni dengan nilai target -1. Parameter yang diambil pada tahap training yaitu shannon entropy dan log energy yang kemudian akan disimpan di dalam database.

Pada tahap testing atau pengujian akan dilakukan dengan 4 orang berbeda. Proses testing akan dilakukan sebanyak 45 kali terdiri dari 15 kali untuk orang pertama, 10 kali untuk orang kedua, 10 kali untuk orang ketiga dan 10 kali untuk orang keempat dengan kondisi cahaya yang cukup dan pengambilan langsung pada waktu yang sama. Berikut alur kerja sistem yang akan melalui beberapa tahapan.

\section{Input}

Pada proses ini mempunyai fungsi untuk memberikan input untuk diproses di dalam laptop. Pada blok input, pengambilan citra menggunakan kamera laptop. Kamera laptop merupakan perangkat yang berfungsi untuk menangkap citra masukan yang akan diuji dan citra yang akan disimpan di database yang selanjutnya akan di proses oleh laptop.

\section{Proses}

Pada blok ini mempunyai fungsi untuk memproses citra masukan yang diakuisisi oleh kamera. Blok proses mempunyai 2 perangkat yaitu laptop dan Arduino Uno.

\section{Laptop}

Perangkat laptop pada blok proses berfungsi untuk pendeteksian wajah menggunakan metode Viola Jones, pengambilan ciri citra menggunakan Transformasi Wavelet dan menggunakan metode Neural Network (NN) Backpropagation untuk pengkalsifikasian dan juga pengenalan pola. Kemudian laptop akan memberi sinyal kepada Arduino Uno. 
2. Arduino Uno

Sebuah perangkat mikrokontroler yang akan mendapatkan hasil olahan citra dari laptop yang kemudian akan memberikan sinyal kepada relay untuk memutus atau tidaknya arus listrik ke solenoid dimana jika ada arus listrik solenoid akan terbuka.

\section{Output}

Pada blok ini merupakan hasil akhir dari proses citra yang merupakan hasil dari keputusan Log. Mikrokontroler merupakan otak dari penggerakan perangkat-perangkat yang ada di blok output. Output mempunyai 2 perangkat yaitu:

1. Relay

Sebuah perangkat elektronika yang memiliki kegunaan untuk menyambung dan memutus aliran listrik. Relay yang akan mengalirkan arus listrik sehingga solenoid terbuka dan juga memutus arus listrik sehingga solenoid tidak terbuka.

2. Solenoid

Perangkat ini yang akan digunakan sebagai kunci yang dipasang pada pintu rumah.
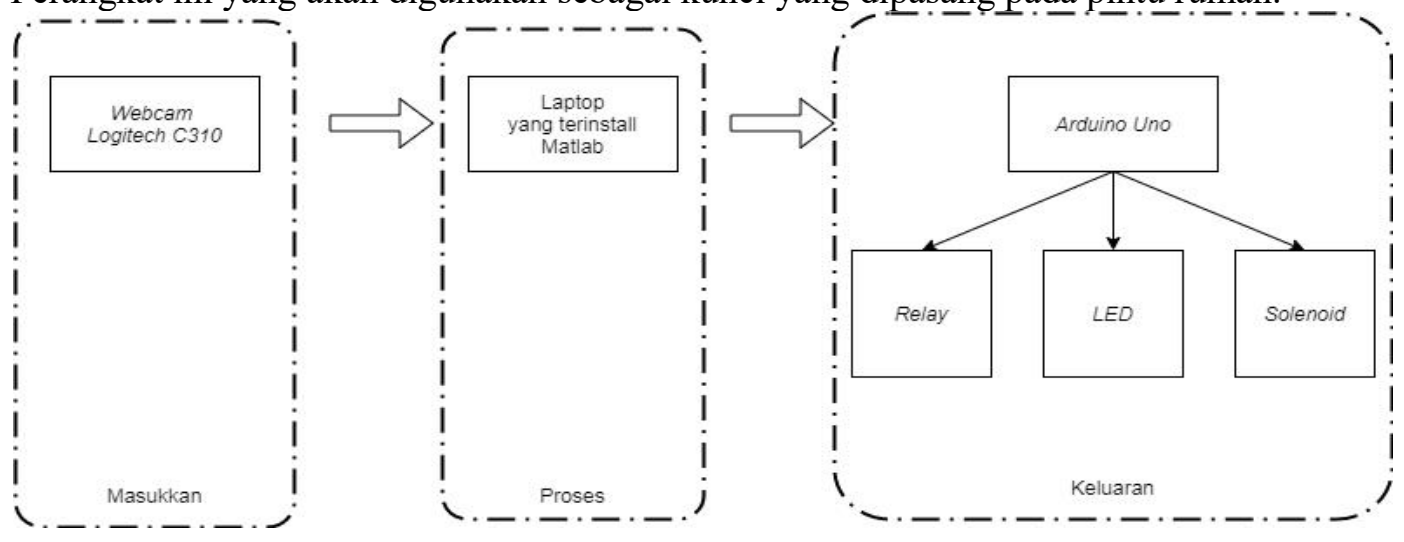

Gambar 5 Blok Diagram

\section{Data Masukan}

ANALISA DAN HASIL

Pada pengenalan sistem keamanan rumah menggunakan pengenalan wajah, input yang merupakan citra dapat berupa jpeg, jpg, png atau dapat menggunakan webcam yang ada di laptop. Berikut adalah tampilan dari program sistem keamanan rumah menggunakan pengenalan wajah.

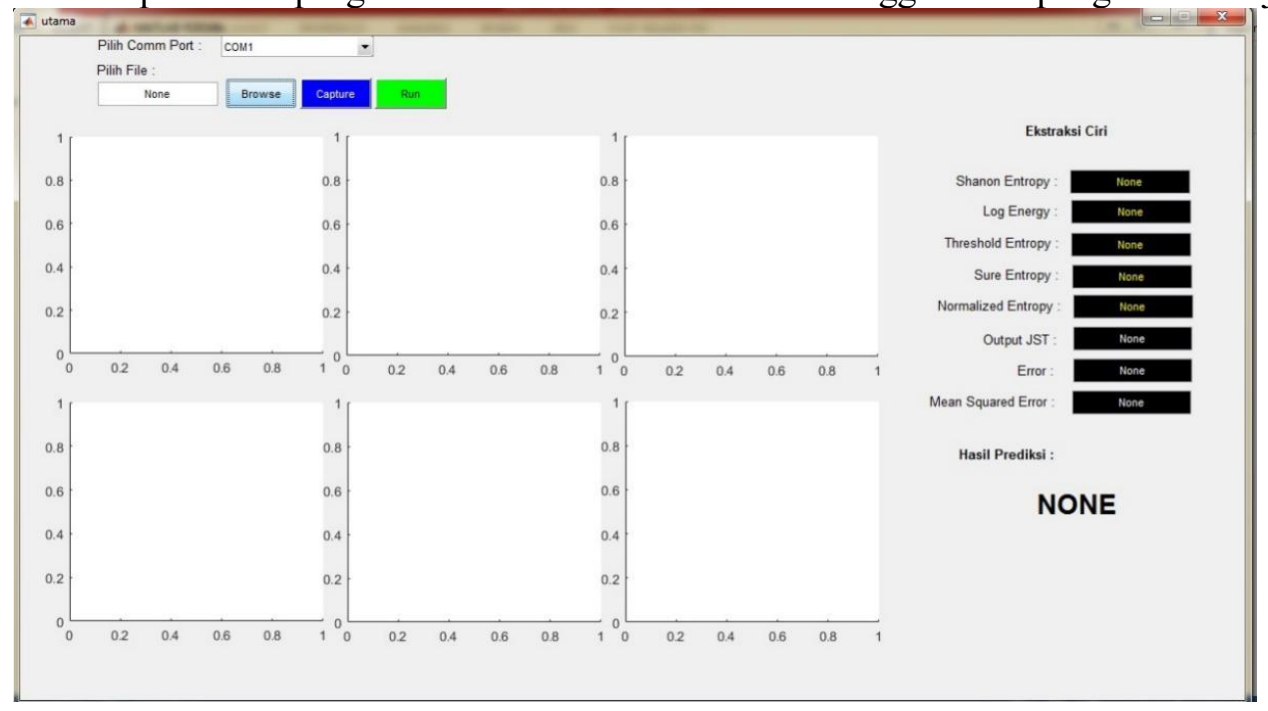

Gambar 6 Tampilan Awal Program 


\section{Data Eror, MSE, dan MAPE}

Perhitungan error merupakan seberapa jauh hasil prediksi citra testing dengan data citra training yang disimpan di database. Sedangkan MSE menghitung besar kesalahan dalam suatu peramalan dan MAPE menghitung persentase kesalahan dalam suatu peramalan.

Tabel 1. Hasil Rata - Rata Error, MSE dan MAPE

\begin{tabular}{ccccc}
\hline Percobaan & Akurasi [\%] & Error & MSE & MAPE [\%] \\
RA & 86,67 & 0,1 & 0,02 & 9,77 \\
RA dengan variasi jarak & 100 & 0,18 & 0,05 & 17,97 \\
$40 \mathrm{~cm}, 50 \mathrm{~cm}, 60 \mathrm{~cm}, 80 \mathrm{~cm}$ dan $100 \mathrm{~cm}$ & & & & \\
AH & 100 & 0,17 & 0,04 & 16,56 \\
SI & 100 & 0,16 & 0,05 & 16,82 \\
AY & 100 & 1,3 & 1,75 & 70,05 \\
Rata- rata & 97,33 & 0,38 & 0,38 & 26,23 \\
\hline
\end{tabular}

Berdasarkan Tabel 1 terlihat hasil dari peramalan citra testing RA sebanyak 15 kali percobaan dengan 2 percobaan gagal atau salah. Pada peramalan ini mempunya rata rata Error sebesar 0,1. Sedangkan untuk Mean Square Error (MSE) sebesar 0,02 dan persentase kesalahan Mean Absolut Percentage sebesar $9,77 \%$.

Hasil dari peramalan citra testing RA dengan variasi jarak $40 \mathrm{~cm}, 50 \mathrm{~cm}, 60 \mathrm{~cm}, 80 \mathrm{~cm}$ dan 100 cm sebanyak 15 kali percobaan dengan 0 percobaan gagal atau salah. Pada peramalan ini mempunya rata rata Error sebesar 0,18. Sedangkan untuk Mean Square Error (MSE) sebesar 0,05 dan persentase kesalahan Mean Absolut Percentage sebesar 17,97\%.

Hasil dari peramalan citra testing AH sebanyak 10 kali percobaan dengan semua percobaan sesuai dengan yang diharapkan yaitu ditolak dikarenakan bukan termasuk penghuni. Pada peramalan ini mempunya rata rata Error sebesar 0,17. Sedangkan untuk Mean Square Error (MSE) sebesar 0,044 dan persentase kesalahan Mean Absolut Percentage sebesar 16,56\%.

Hasil dari peramalan citra testing SI sebanyak 10 kali percobaan dengan semua percobaan sesuai dengan yang diharapkan yaitu ditolak dikarenakan bukan termasuk penghuni. Pada peramalan ini mempunya rata rata Error sebesar 0,16. Sedangkan untuk Mean Square Error (MSE) sebesar 0,05 dan persentase kesalahan Mean Absolut Percentage sebesar 16,82 \%.

Hasil dari peramalan citra testing AY sebanyak 10 kali percobaan dengan semua percobaan sesuai dengan yang diharapkan yaitu ditolak dikarenakan bukan termasuk penghuni. Pada peramalan ini mempunya rata rata Error sebesar 1,3. Sedangkan untuk Mean Square Error (MSE) sebesar 1,75 dan persentase kesalahan Mean Absolut Percentage sebesar 70,05 \%.

\section{Delay Waktu}

Pada pembahasan ini, menghitung seberapa lama sistem ini mengenali suatu citra masukkan dalam sekali percobaan. Perhitungan delay Waktu menggunakan alat Stopwatch.

\begin{tabular}{cc}
\hline Tabel 2. Hasil Rata - Rata Delay Waktu \\
\hline Nama & Rata - Rata \\
& Delay \\
RA & 7,5 \\
AH & 8,97 \\
SI & 9,15 \\
AY & 8,53 \\
Rata- Rata Keseluruhan & 8,53 \\
\hline
\end{tabular}


Berdasarkan Tabel 2 rata - rata dari keseluruhan sistem dalam mengenali objek atau citra selama 8,53 detik. Rata-rata delay waktu tercepat terjadi saat pengenalan RA 7,5 detik. Rata-rata delay waktu terlama terjadi saat pengenalan SI selama 9,15 detik.

\section{Kesimpulan}

\section{KESIMPULAN DAN SARAN}

Berikut ini hasil dari penelitian yang telah dilakukan. Pemodelan ini mempunyai desain pada Jaringan Saraf Tiruan yaitu 2-40-5-1 dimana angka 2 merupakan input layer yang masukkannya merupakan hasil ekstraksi fitur. Angka 40 merupakan hidden layer 1 dan angka 5 adalah hidden layer 2 dan angka 1 adalah output layer. Pemodelan ini menghasilkan akurasi 97,33\%, error sebesar 0,38, mean square error sebesar 0,38 , dan mean absolute percentage sebesar $26,23 \%$. Untuk error Terbesar terjadi pada percobaan bukan penghuni dan tidak terdapat di database. Sedangkan error Terkecil berada pada RA yang termasuk penghuni dan ada di dalam database. Pemodelan ini mempunyai delay waktu rata - rata selama 8,53 detik.

\section{Saran}

Merealisasikan pemodelan sebagai suatu sistem yang terintegrasi dan proses tidak lagi menggunakan laptop melainkan dengan mikrokontroler. Penelitian ini juga hanya menggunakan dekomposisi level 1 dan Wavelet Daubechies yang bisa ditambah level dekomposisi atau jenis keluarga Wavelet yang dipakai sepert Bior dan Gabor yang bisa dipakai untuk pencirian.

\section{DAFTAR REFERENSI}

[1]. A. R. Syakhala, D. Puspitaningrum, and E. P. Purwandari, "Perbandingan Metode Principal Component Analysis (PCA) dengan Metode Hidden Markov Model (HMM) dalam Pengenalan Identitas," J. Inform., vol. 3, no. 2, pp. 68-79, 2015.

[2]. I. Sharif and S. Khare, "Comparative Analysis of Haar And Daubechies Wavelet for Hyper Spectral Image Classification," Int. Arch. Photogramm. Remote Sens. Spat. Inf. Sci., vol. XL-8, pp. 937-941, 2014.

[3]. M.Razak, "Peramalan Jumlah Produksi Ikan Dengan menggunakan Backpropagation Neural Network,’Tugas Akhir, Institut Teknologi Sepuluh Nopember, Surabaya, 2017.

[4]. A. Atiliani, "Pelatihan Jaringan Saraf Tiruan Multi Layer Perceptron Menggunakan Genetic Algorithm Levenberg Marquardt," Tugas Akhir, Universitas Sebelas Maret, Surakarta, 2013.

[5]. H. Simaremare dan A. Kurniawan, "Perbandingan Akurasi Pengenalan Wajah Menggunakan Metode LBPH dan Eigenface dalam Mengenali Tiga Wajah Sekaligus secara Real-Time," J. Sains, Teknol. dan Ind., vol. 14, no. 1, pp. 66-71, 2016.

[6]. H. Candra, M. Yuwono, R. Chai, H. Nguyen, and S. Su, "Classification of Facial-Emotion Expression in the Application of Psychotherapy using Viola-Jones and Edge-Histogram of Oriented Gradient," IEEE, pp. 423-424, 2016.

[7]. Z. Hua and M. N. Chong, "Wavelet-denoising approach for removing background noise in medical images," in Proceedings of the International Conference on Information, Communications and Signal Processing, ICICS, 1997.

[8]. Sriani, Triase, dan Khairuna, "Pendekomposisian Citra Digital Dengan Algoritma DWT," J. Ilmu Komput. dan Inform., vol. 1, no. 1, pp. 35-39, 2017.

[9]. C. Reza, "Teknik Potensi Diferensial pada Transformator Daya Tiga Fasa dengan Menggunakan Transformasi Wavelet,'Tugas Akhir, Universitas Pendidikan Indonesia, Bandung, 2013.

[10]. S. N. Wibowo, B. Hidayat, dan J. Arif, "Identifikasi Jenis Batuan Beku Melihat Bentuk Pola Batuan Menggunakan Metode Discrete Wavelet Transform (DWT) dan K-Nearest Neighbor (KNN)," e-Proceeding Eng., vol. 4, no. 2, pp. 1677-1684, 2017.

[11]. M. Felyana, "Watermarking Video Menggunakan Transformasi Wavelet Diskrit," J. GENERIC, vol. 8, no. 1, pp. 198-208, 2013.

[12]. S. Agoes, Reduksi Noise pada Citra Menggunakan Transformasi Wavelet. Tesis, Universitas Indonesia, Depok, 1998.

[13]. E. Siti, A. Hayat, P. Widanti, S. Yulinda, dan H. Iskandar, "Analisis Kemiripan Pola Citra Digital Menggunakan Metode Euclidean," Semin. Nas. Teknol. Inf. dan Multimed., vol. 5, no. 4, pp. 13-18, 2015. 
[14]. M. Rin Rin, "Analisis Mean Square Error (MSE) Proses Pelatihan Menggunakan Metode Backpropagation dengan Self Organizing Maps dan Nguyen-Withdrow," Tesis, Universitas Sumatera Utara, Medan, 2015 